\title{
Student Mastery of Association Concept in Aceh Selatan Polytechnic Computer Engineering Program
}

\author{
Fera Anugreni $^{\mathrm{a}, 1, *}$, M. Anhar Pulungan ${ }^{\mathrm{b}, 2}$, Asmaidic ${ }^{\mathrm{c}, 3}$ \\ aDepartement of Computer Engineering, Polytehcnic of Aceh Selatan, Tapaktuan, 23711, Indonesia \\ *anugrenifera28@gmail.com, anhar.240205@gmail.com, asmedmat@gmail.com
}

ARTICLE INFO

Article history:

Accepted

Keywords:

Mastery

Contextual Teaching and

Learning Association

\section{ABSTRACT}

Mathematical Association material becomes difficult for students to learn since it is described in the form of set-forming notation and story-based questions (applied). Moreover, they find it difficult to determine the number of subsets with several determined members. The author's observations while teaching at the South Aceh Polytechnic Computer Engineering Study Program for the 2018/2019 academic year obtained data that students did not master Discrete Mathematics subjects, especially the material of the Association. This can be seen in daily assignments, midterm exams, and final semester exams. The author as a lecturer in the Study Program was disappointed with the results obtained. The approach and type of this research is a quantitative approach and a pure experimental type of research. The research sample of the second-semester students of the South Aceh Polytechnic Computer Engineering Study Program for the 2019/2020 academic year was 16 students. The research data was the test scores collected from students. The instrument in this study was a test question. The data collection technique in this research is a written test. Data analysis used t-test at a significant level $\alpha=0,05, d k=4$, with standard value of $\mu_{0}=69$. Based on the analysis gained $t_{(0,95)(15)}=t_{\text {Tabel }}=1,75$ and $t_{\text {Hitung }}=1,83$. Thus, the result turns out $t_{\text {Hitung }}>t_{\text {Tabel }}$ or $1.83>1,75$. Thus it is concluded that the mastery of Computer Engineering Study Program students at the Polytechnic of South Aceh for the 2019/2020 academic year in understanding the set material has reached a level of success.

Copyright () 2020 Politeknik Aceh Selatan. All rights reserved.

\section{Introduction}

\section{A. Background}

Discrete Mathematics is a discipline of mathematics taught in universities. In general, students know the importance of learning discrete mathematics and its implementation in everyday life. Therefore, discrete mathematics needs to be understood and mastered by every student so that all things that have to do with mathematics can generally be solved.

On the other hand, students' performance in discrete mathematics is considered low. This can be seen in the results of daily assignments, midterm exams, and final semester exams. The author experienced this when teaching in class B semester II of the South Aceh Polytechnic Computer Engineering Study Program for the 2018/2019 academic year. The author, as a lecturer in the Study Program, was reluctant with the results obtained, especially on the association material. The material of the set or association is one of the materials contained in the Discrete Mathematics course. The material becomes difficult for students to learn. Students find it difficult to answer questions if the problem is given in the form of set-forming notation and story problem form (applied) and students find it difficult to determine the number of subsets whose many members are determined. 
Based on this, the researcher conducted an alternative action to solve the existing problem in the form of a learning process using a learning approach Contextual Teaching and Learning (CTL). In a contextual approach, a learning concept where lecturers present real-world situations into the classroom and encourage students to make connections between their knowledge and its application in their lives as family and community members. Thus students understand the meaning of learning, what are its benefits, in what status they are, and how to achieve it. The contextual approach is also defined as a learning approach that emphasizes the importance of the natural environment being created in the learning process so that the class is more lively and meaningful because students experience what they learn for themselves. According to [1], in the CTL approach there are seven components, namely: (1) Constructivism, (2) Finding, (3) Asking, (4) Learning Society, (5) Modeling, (6) Reflection, and (7) Authentic Assessment.

According to [2], "CTL learning is a competency-based learning model that can be used to make the implementation of 2004 more effective and successful. In contextual learning, students are required to understand the meaning of learning and learning objectives and be useful for future life ". Then, based on research conducted by [3], it was found that "the LKS IPS product based on a contextual approach was feasible to use. The material expert's assessment obtained results with good criteria. This indicates that the material presented is following SK and KD, LKS IPS can accommodate a contextual approach, the language used is following the stages of student development, and the presentation can be understood clearly, attractively and interactively ". Following this discussion, the researcher tries to apply the CTL learning approach because it can provide better results.

\section{B. Problem Formulation}

The formulation of the problem in this research is: Has the mastery of the students of the Computer Engineering Study Program at the South Aceh Polytechnic of the 2019/2020 academic year in understanding the material of the set has reached a success level?.

\section{Purpose}

The purpose of this study was to determine the ability of students of the Computer Engineering Study Program at the Polytechnic of South Aceh for the 2019/2020 academic year in understanding the set material.

\section{Literature Review}

\section{A. Learning}

Learning is a process characterized by changes in a person. Change as a result of the learning process can be shown in various forms, such as changes in knowledge, understanding, behavior, skills, habits, and changes in the aspects that exist in individuals who are learning. According to [4], learning is a change in behavior towards better behavior, where these changes occur through practice or experience. Furthermore [5], explained that learning and teaching as the main activities in school include three elements, namely teaching objectives, teaching and learning experiences, and learning outcomes.

\section{B. Factors Affecting Learning}

Behavior as a result of the learning process is strongly influenced by many factors, both factors that are within the individual and factors that are outside the individual.

1) Internal factors, namely factors that come from within yourself, including the following:

a) Physiological conditions.

b) Psychological conditions includes: 1) intelligence, 2) talent, 3) interest and attention, 4) motivation, 5) emotion, and 6) cognitive abilities.

2) External factors, namely factors that come from outside of oneself, both that exist in the family environment, in the school environment, or the community.

a) Family environmental factors such as family economic conditions, harmony family, family education level, and so on.

b) School environmental factors such as teachers, learning facilities, curriculum, friends, classrooms, school rules, the social situation at school, and so on

c) The school environment mentioned above essentially functions as a student learning 
environment, namely the environment where students interact, thereby fostering learning activities in themselves.

d) The community environment, such as the influence of social interactions, social situations, cultural influences such as films, soap operas, readings, and so on.

\section{Learning Outcomes}

The word learning outcomes can be identified with the word learning achievement, namely the results obtained after learning. As an illustration, the following is an opinion about learning achievement. Sunaryo argues that learning achievement is a person's ability to master several programs after the program is completed. The results of this achievement are symbolized in the form of numbers (values) so that they reflect the success of learning or student achievement in a certain period [6].

\section{Contextual Teaching and Learning}

The Contextual Teaching and Learning approach is an educational process that aims to help students see meaning in the learning material they learn by relating it to the context of their daily lives, namely the context of their personal, social, and cultural environment [7].

\section{Research Method}

\section{A. Approach and Type of Research}

The approach used in this research is quantitative. This type of research is categorized into quasi-experimental research with a "one-shot case study" design, which is described as follows:

Information:

\section{\begin{tabular}{|l|l|}
\hline $\mathrm{X}$ & $\mathrm{O}$ \\
\hline
\end{tabular}}

$\mathrm{X}=$ Treated

$\mathrm{O}=$ Result [8].

\section{B. Population and Research Sample}

The population in this study were all students of the South Aceh Polytechnic Computer Engineering Study Program. The research sample of the second-semester students of the South Aceh Polytechnic Computer Engineering Study Program for the 2019/2020 academic year. The number of students is 16 students.

\section{Data and Data Sources}

The data in this study were the students' scores which came from the test results given after the learning was complete.

\section{Assessment Instruments}

The instrument in this study was in the form of test questions consisting of several questions. It aims to obtain data in the form of student test scores. Test questions are given to determine the student's ability to master the set material.

\section{E. Data Collection Techniques}

Data collection techniques in this study were test questions. The test is given twice. The test score in this study is the average value after two tests.

\section{F. Data Analysis Techniques}

To obtain research results, several calculations are required:

a) For data that has been compiled in a frequency distribution list, according to [9], the average value is calculated by a formula:

$$
\bar{x}=\frac{\sum f_{i} x_{i}}{\sum f_{i}}
$$

b) To calculate the variance $\left(S^{2}\right)$ formula can be used:

$$
S^{2}=\frac{n \sum f_{i} x_{i}^{2}-\left(\sum f_{i} x_{i}\right)^{2}}{n(n-1)} .
$$

then tested the requirements of the t-test, namely:

c) Normality Test 


$$
\chi^{2}=\sum_{i=1}^{k} \frac{\left(O_{i}-E_{i}\right)^{2}}{E_{i}}
$$

Information:

$$
\begin{aligned}
& \chi^{2}=\text { chi-square statistic } \\
& O_{i}=\text { observation frequency } \\
& E_{i}=\text { the expected frequency }
\end{aligned}
$$

If the data is normally distributed, the t-test with a significant level is used $\alpha=0,05$ and $d k$ $=n-1$, with the formula:

$$
t=\frac{\bar{x}-\mu_{0}}{\frac{s}{\sqrt{n}}}
$$

Information:

$$
\begin{array}{rll}
\overline{\mathrm{x}} & : \text { Mean } \\
S & : & \text { Standard Deviation } \\
\mu_{0} & : & 69, \text { is a standard value which states that students have mastered } 69 \% \text { of the } \\
n & : \text { lesson objectives. }
\end{array}
$$

Furthermore, the data will be confirmed with predetermined criteria that a student is called complete learning if he gets a score of at least $69 \%$ of the total score.

\section{Results and Discussion}

A. Data

$\begin{array}{llllllll}92 & 73 & 78 & 52 & 84 & 84 & 63 & 68 \\ 75 & 77 & 87 & 72 & 73 & 89 & 57 & 61\end{array}$

\section{B. Data Analysis}

\section{1) Normality Test of Data Distribution}

Based on the analysis of the study test data obtained an average value $(\bar{x})$, variance $\left(S^{2}\right)$, and standard deviation (S) respectively $72,118,8$ dan 10,9. Furthermore, the normality test of the learning test data was obtained $X_{\text {Hitung }}^{2}=0,96$ and $X_{\text {Tabel }}^{2}=9,49$. Using the Chi-Square test at a significant level $\alpha=0,05$ and $d k=4$ obtained $X_{\text {Hitung }}^{2}<X_{\text {Tabel }}^{2}$ or $0,96<9,49$, it is concluded that the distribution of student learning test data follows the normal distribution.

\section{2) Hypothesis Testing}

At a significant level $\alpha=0,05$ and degrees of freedom $\mathrm{dk}=\mathrm{n}-1, \mathrm{dk}=16-1=15$. From the distribution, list $t$ is obtained $t_{(0,95)(15)}=t_{\text {Tabel }}=1,75$. Using equation (7) the value is obtained $t_{\text {Hitung }}=1,83$. Based on these results obtained $t_{\text {Hitung }}>t_{\text {Tabel }}$ or $1,83>1,75$. Thus the hypothesis in this study states that the mastery of the Computer Engineering Study Program at the South Aceh Polytechnic of the 2019/2020 academic year in understanding the set material has reached a level of success.

\section{Discussion}

In learning, a lecturer must be able to provide optimal and fair service to all students. Lowability students get services according to their potential. In general, those who fall into this group are slow to learn. Therefore, they must receive services according to their learning slowness. The same is the case with students of average ability and high ability. To realize the learning process as above, the lecturer must make learning that attracts students to learn and compiles an instrument that is following what students are learning so that students answer the questions given. 
Student activities during learning are carried out involving interest, response, and attention. This is shown by the enthusiastic attitude of students towards ongoing learning, such as attention to lecturers' explanations, finding their set concepts. Learning with the CTL approach encourages students to take actions based on the knowledge including movement such as the ability to define problems, conduct experiments, analyze the formulation, and collaborate which encourages students to engage and deliver ideas deliberately.

\section{Conclusion}

\section{A. Conclusion}

Based on the research results, it can be concluded that: Based on the data analysis carried out, it can be concluded that the course mastery in the Computer Engineering Study Program at the South Aceh Polytechnic of the 2019/2020 academic year in understanding the set material has reached a level of success.

\section{B. Suggestion}

Based on the research conclusions, several suggestions are given as follows: 1) the lecturers will provide more exercises on association material to strengthen students performance, and 2) Thus, students will actively engage and learn well in the learning process, to increase mastery of the concept of set.

\section{Acknowledgment}

Ackonwledgement It will be the greatest thanks to KEMENDIKBUD-DIKTI due to the main contribution in PDP scheme for its grant, to LL Dikti chapter XIII Banda Aceh as the facilitator. Not to mention, the writer gratitude to Director, Vice Director 1 and Vice Director 2 of South Aceh Polythecnics to their ideas, suggesstion and support in order to complete this work.

\section{References}

[1] Sutawijaya dkk. 2011. Pembelajaran Matematika. Jakarta: Universitas Terbuka.

[2] Mulyasa, E. 2005. Menjadi Guru Profesional. Cetakan Ketiga. Bandung: PT Remaja Rosdakarya.

[3] Isnanto. 2016. Pengembangan Lembar Kerja Siswa Berbasis Pendekatan Pembelajaran Contextual Teaching and Learning (CTL) Materi Pokok Kegiatan Ekonomi di Indonesia Siswa Kelas V SD. Program Studi Sekolah Dasar. Universitas Negeri Yogyakarta.

[4] Nidawati. 2013. Belajar dalam Perspektif Psikologi dan Agama. Jurnal Pionir Volume 1(1) Juli-Desember 2013.

[5] Kasmawati dkk. 2017. Pengaruh Model Pembelajaran Contextual Teaching and Learning (CTL) Terhadap Hasil Belajar. Jurnal Pendidikan Fisika Volume 5(2), Hal. 70-75, September 2017 ISSN: 2355-5785. Pendidikan Fisika: UIN Alauddin Makassar.

[6] Djaka Suherna. 2002. Belajar dan Pembelajaran. Semarang: CV.IKIP Semarang Press.

[7] Nurhadi, dkk. 2004. Kurikulum 2004 Pertanyaan dan Jawaban. Jakarta: Gramedia.

[8] Arikunto, Suharsimi. 2005. Prosedur Penelitian Suatu Pendekatan Praktik. Jakarta: Rineka Cipta.

[9] Sudjana. 2005. Metoda Statistika. Bandung: Tarsito. 